\author{
Anna Mlekodaj \\ Podhalańska Państwowa Uczelnia Zawodowa \\ Nowy Targ \\ ORCID 0000-0001-9883-2320; e-mail anna.mlekodaj@ppuz.edu.pl
}

\title{
O gwarowej artystycznej metaforze niekonwencjonalnej na przykładzie poezji Podhala
}

\begin{abstract}
Abstrakt: W gwarowej poezji Podhala obok nurtu ludowego wyodrębnił się także nurt zindywidualizowanej liryki, prezentującej subiektywną wizję świata, przefiltrowaną przez wrażliwość poety. Teksty należące do tego nurtu cechuje niekonwencjonalna metaforyka, polegająca na zastosowaniu figur stylistycznych świadomie i twórczo modyfikujących konwencje ludowego stylu artystycznego lub też inspirujących się innymi wzorcami. Celem niniejszego artykułu jest analiza czterech przykładów niekonwencjonalnych metafor gwarowych o różnym stopniu złożoności. Wszystkie zostały zaczerpnięte z tekstów współczesnych poetów Podhala. W nawiązaniu do interakcyjnej teorii metafory M. Blacka zostaną omówione przekształcenia semantyczne, którym poddano poszczególne wyrażenia gwarowe w celu wydobycia z nich nowych znaczeń.
\end{abstract}

Słowa kluczowe: gwara podhalańska, poezja, metafora, przekształcenia semantyczne.

\begin{abstract}
A subdialectal, unconventional artistic metaphor: the example of poetry from Podhale, Poland. Poetry written in Podhale includes the folk trend together with individualised poetry, presenting a subjective vision of the world, processed by the poet's sensitivity. The texts attributed to this trend present unconventional poetic metaphors where use is made of stylistic devices purposefully and creatively modifying the conventions of the folk style or inspired by other standards. The aim of this article is to analyse four examples of unconventional poetic metaphors of varying complexity. All of them come from the texts written by contemporary poets from Podhale. With reference to M. Black's interactive theory of metaphor, the semantic transformations of individual dialectical expressions are discussed in order to decipher new meanings.
\end{abstract}

Key words: Podhale dialect, poetry, metaphor, semantic transformations.

\section{Wprowadzenie}

Literatura gwarowa, jeśli w ogóle istnieje, z wielu powodów rozwija się wolniej i cieszy mniejszym zainteresowaniem niż jej ogólnopolska odpowiedniczka. Nie chodzi tu wyłącznie o tendencję do unifikacji językowej; wiadomo bowiem, że gdzie gwara jest $\mathrm{w}$ regresie, tam raczej nie wykorzystuje się jej w procesie twórczym. Wciąż jednak istnieją regiony, w których gwary wykazują znaczną żywotność, co między innymi manifestuje się twórczością literacką. Być może zresztą oba te fakty należy połączyć, przyjmując tezę, że gwary, które wykształciły literaturę, przetrwały i nadal 
cieszą się dobrą kondycją, podczas gdy inne, oparte wyłącznie na przekazie ustnym, uległy częściowej lub całościowej dezintegracji.

Jakie więc są powody trudnej sytuacji literatury gwarowej?

Pierwsza grupa przyczyn tego stanu rzeczy pozostaje w ścisłym związku z oralną naturą gwary, która dopiero w XX w. zaczęła sobie stopniowo przyswajać pismo. Mimo to nawet tak zaawansowana literacko jak podhalańska $\mathrm{w}$ dalszym ciągu nie ma wypracowanej jednolitej ortografii i wciąż sprawia problemy zarówno piszącym, jak i czytelnikom ${ }^{1}$. Po drugie użytkownik gwary $z$ trudem przyswaja sobie pisane teksty gwarowe. Mówienie gwarą nie jest wcale jednoznaczne $\mathrm{z}$ biegłością w jej czytaniu². Dla dużej części odbiorców gwara w zapisie jest wciąż zjawiskiem nowym i częściowo obcym, a jego upowszechnienie wymagałoby stosownej edukacji, której z wielu powodów nie ma i jeszcze zapewne długo nie będzie. Po trzecie wreszcie w piśmie gwara z konieczności wprowadza pewnego rodzaju unifikację; utrwala i popularyzuje zjawiska, które w żywej mowie charakteryzowały mieszkańców jakiegoś wyodrębnionego subregionu. Ze swej natury pismo zmienia gwarę, czyniąc ją w miarę sprawnym narzędziem komunikacyjnym w obrębie całego regionu, niwelując różnice, dzięki którym w bezpośrednim kontakcie rozmówca identyfikował w przybliżeniu miejsce, skąd pochodził jego interlokutor. $\mathrm{Z}$ tego też powodu gwara utrwalona w piśmie często spotyka się u autochtonów $\mathrm{z}$ opinią, że to nie jest do końca po nasymu. Bo też i być nie może.

Druga grupa powodów trudnej sytuacji literatury gwarowej wiąże się z brakiem lub ograniczonym zakresem zjawiska, które można by określić jako kultura literacka. Według Michała Głowińskiego zjawisko to obejmuje kompleks sądów dotyczących literatury, jej znaczenia, wartości, istoty, celów, świadomość jej podziałów i wewnętrznego zróżnicowania, który charakteryzuje w danym czasie określoną grupę społeczną, podzielającą zainteresowania sztuką (Głowiński 1988, 245). Janusz Sławiński natomiast upatruje w kulturze literackiej rodzaj „systemu orientacyjnego”, który pozwala jej współtwórcom na skuteczne porozumiewanie się przez dzieła. Łączy się to z kompetencją w zakresie rozumienia i wartościowania znamiennych dokonań z zakresu literatury, gustem rozumianym jako szczególne upodobanie określonych form, a także tzw. oczytaniem, dającym możliwość odpowiedniego zaklasyfikowania nowo powstałych dzieł (Sławiński 1998, 37-39)3. W tradycyjnych społecznościach wiejskich, dla których

\footnotetext{
1 Wielkie znaczenie dla ujednolicenia zapisu gwary podhalańskiej ma Ilustrowany leksykon gwary $i$ kultury podhalańskiej Józefa Kąsia, a mimo to wciąż jeszcze ortografia pozostaje rozchwiana i nic nie wskazuje na to, aby w najbliższym czasie uformowało się u piszących Podhalan poczucie gwarowej normy ortograficznej.

${ }^{2}$ Problem z czytaniem tekstów gwarowych uwidocznił się przy okazji konkursu literacko-plastycznego „Góralskie cytanie”, który odbywa się na Podhalu, Spiszu, Orawie i ziemi zagórzańskiej od kilku lat. Dzieci pracują z odpowiednio dobranymi do wieku tekstami z czytanek gwarowych, w których są opowiadania w ich rodzimej gwarze (każdy region ma własną czytankę), a mimo to, jak podkreślają przygotowujący uczniów nauczyciele, czytanie gwary nie przychodzi im łatwo. O wiele łatwiej jest im recytować z pamięci wyuczony wiersz niż czytać fragment opowiadania, a następnie opowiadać jego treść własnymi słowami (w gwarze).

3 Próby integracji środowiska poetów tworzących gwarą były widoczne już w latach 70. XX w. Najstarszą z nich jest formuła „Święta góralskiej poezji”, które ma już blisko czterdziestoletnią tradycję. Organizowane corocznie w Rabie Wyżnej (Mlekodaj 2014), w latach 90. przeżywało swój renesans. W tym samym
} 
gwara była podstawowym narzędziem komunikacji, wszelką twórczość słowną regulowały zasady wpisane w naturę folkloru. Funkcjonujące w jego przestrzeni teksty cechowały: wspólnotowość, wykluczająca pojęcia autorstwa w rozumieniu, które przyniosła literatura, oralność połączona z synkretyzmem środków i sposobów przekazu typowym dla naturalnej sytuacji folklorystycznej oraz estetyzm, oparty na stałym repertuarze konwencji utrwalonych w kolejnych przekazach i akceptowanych przez wszystkich uczestników (Bartmiński 1990, 10-11). W miarę ustępowania folkloru jego miejsce zaczęła zajmować twórczość literacka. Na Podhalu częściowo nawiązuje ona do tradycji folkloru i także współcześnie nie wychodzi poza jego estetykę. Metaforyka, do której odwołują się twórcy tego nurtu, mieści się w interpretacyjnych ramach ludowego stylu artystycznego (Bartmiński 2001, 223-234). Równolegle jednak funkcjonuje drugi typ gwarowej poezji, który świadomie kreuje odmienną wizję świata. Cechuje się on wysokim poziomem indywidualizmu oraz twórczą interpretacją konwencji utrwalonych przez poetykę folkloru, a niekiedy wręcz całkowitym ich odrzuceniem na rzecz inspiracji współczesną polską poezją. Konsekwencją takich założeń jest odmienne podejście do gwary. Jako tworzywo poezji jest ona w procesie twórczym poddawana niekonwencjonalnym semantycznym przekształceniom, w tym różnym formom metaforyzacji. Ze względu na innowacyjność i związaną z nią trudność w lekturze, a także właśnie brak koniecznej do ich odbioru kultury literackiej, utwory poetów tego nurtu nie cieszą się zbyt wielką popularnością. Tomiki ich poezji rozchodzą się w niskich nakładach (od 100 do 300 egzemplarzy). Rzadko też bywają wznawiane. Wśród odbiorców dominują uczestnicy lub organizatorzy licznych na Podhalu konkursów recytatorskich. Pozostałą część stanowi wąska grupa miłośników góralskiego słowa, nierzadko także spoza Podhala. Mimo to właśnie poetom o twórczym i niekonwencjonalnym podejściu do gwary zawdzięcza ona żywotność w czasach, kiedy jej naturalne źródła straciły już swoją siłę.

\section{Cel}

Celem niniejszego artykułu jest analiza gwarowych poetyckich metafor niekonwencjonalnych. Rozumiem przez nie takie przekształcenia semantyczne, które świadomie modyfikują metaforykę mieszczącą się w konwencji ludowego stylu artystycznego lub też realizują zupełnie inne wzorce. Zakres problemu badawczego artykułu wyznaczają następujące pytania:

\footnotetext{
okresie w wyniku łatwiejszego dostępu do publikacji, gwarowa poezja Podhala znacznie się wzbogaciła i rozwinęła. Poeci zaczęli także inicjować kameralne otwarte spotkania, w celu czytania wierszy. W MOK-u w Nowym Targu w latach 2004-2016 odbywały się cykliczne spotkania poetyckie pod nazwą warsztatów literackich. Z inicjatywy podhalańskich poetów (Krzysztofa Kokota, Wandy Szado-Kudasikowej, Renaty Lipkowskiej) organizowano (przed pandemią wirusa Covid19) podhalańsko-śląskie biesiady literackie, odbywane naprzemiennie w Nowym Targu i w Katowicach lub Rybniku. Efektem tych działań jest, poza popularyzacją gwarowej poezji, wytworzenie w środowisku osób piszących świadomości warsztatowej oraz krystalizacja tego, co Sławiński określa terminem ,gust”, a co jest składową kultury literackiej. Zjawiska te mają jednak ściśle elitarny charakter i tylko w niewielkim stopniu przekładają się na świadomość literacką ogółu mieszkańców regionu.
} 
- czy metafora gwarowa różni się od klasycznej metafory literackiej, a jeśli tak, to w jakich aspektach?

- jakie są podstawowe mechanizmy tworzenia gwarowych metafor niekonwencjonalnych?

- kiedy metafory takie można uznać za udane oraz czy rozwijają one gwarę, a jeśli tak, to w jakim zakresie?

Materiału badawczego dostarczyły gwarowe utwory podhalańskich poetów, opublikowane na przełomie XX i XXI wieku w samodzielnych tomikach poetyckich. Z poszczególnych wierszy wybrano wyrażenia metaforyczne, które na tle gwarowej poezji Podhala $^{4}$ charakteryzują się indywidualizmem oraz twórczym podejściem do językowego tworzywa.

\section{Metoda}

Ze względu na to, iż analizie zostaną poddane gwarowe metafory artystyczne, wykreowane przez poetę na potrzebę wypowiedzi funkcjonującej w obrębie literackiej komunikacji językowej, za podstawę metodologiczną przyjmuje się klasyczną teorię metafory Maxa Blacka $(1971,1983)$. Wyróżnia on trzy mechanizmy, które na różne sposoby tłumaczą fenomen powstawania przenośnego sensu wypowiedzi.

Pierwszy polega na tym, iż wyrażenie metaforyczne po prostu zastępuje wyrażenie literalne. Powodem tego zastąpienia jest potrzeba powiedzenia czegoś w niebanalny sposób (względy stylistyczne) lub też uzupełnienie braku w słowniku (względy praktyczne - katachreza). Sformułowana na tej podstawie substytucyjna teoria metafory głosi, że każde wyrażenie metaforyczne jest możliwe do zrozumienia dzięki znajomości literalnego odpowiednika słowa użytego przenośnie lub też na mocy leksykalizacji pewnych sposobów przenośnego opisywania rzeczywistości (por. Lakoff, Johnson 1988).

Drugi mechanizm metaforotwórczy wywodzi się z dostrzeżenia i wyeksponowania ukrytego, mniej lub bardziej nieoczywistego podobieństwa między znaczeniem słowa użytego przenośnie, a znaczeniem słowa rozumianego literalnie. Dało ono podstawę porównaniowej teorii metafory, głoszącej, iż sens przenośny wyrażenia jest wynikiem zagęszczonego lub skróconego porównania, do którego zawsze można sprowadzić daną metaforę. Porównaniowa teoria metafory obejmuje wyrażenia tworzone drogą zestawienia dwóch rzeczowników z pominięciem językowego sygnału porównania. W gruncie rzeczy metafory wywodzące się z eliptycznych porównań są odmianą metafor substytucyjnych, ponieważ słowo użyte metaforycznie daje się w nich zastąpić słowem rozumianym literalnie, choć zastąpienie takie wprowadza wyraźne uszczuplenie treści.

Trzeci mechanizm metaforyzacji polega na uaktywnieniu w świadomości odbiorcy „systemu banalnych skojarzeń” ewokowanych przez zestawienie w wyrażeniu metafo-

${ }^{4}$ Ogólne tło garowej poezji Podhala jest możliwe do uchwycenia dzięki antologiom, które dają wgląd w jej rozwój na przestrzeni XX i XXI wieku. Mam tu na myśli następujące zbiory: Nuty serdeczne, red. i oprac. A. Kudasik i in., Nowy Targ 1998; Bukowiańskie nuty, oprac. A. Mlekodaj, Bukowina Tatrzańska 2005; Góralskie serce w zielonym listku pieśni. Antologia poezji regionu Podtatrza, red. i oprac. A. Mlekodaj, Ludźmierz 2006; Na pokrzepę tobie. Antologia, red. i oprac. A. Mlekodaj, Raba Wyżna 2014. 
rycznym pojęć, z których jedno jest przedmiotem głównym, a drugie - pomocniczym. W omawianej przez Blacka metaforze czlowiek jest wilkiem, pojęcie człowiek jest przedmiotem głównym. Rozumiane literalnie stanowi ono ramę metafory, w której mieszczą się tylko pewne, wybrane cechy przedmiotu pomocniczego - wilka, będącego źródłem metafory. Interakcja zachodząca między zestawionymi pojęciami jest zaprogramowana tak, aby w świadomości odbiorcy zaktywizować wyłącznie te cechy wilka, które najlepiej posłużą zdefiniowaniu człowieka w odpowiednim kontekście. Interakcja ta jest więc projekcją wybranych cech pola semantycznego wyrazu pomocniczego na przedmiot podstawowy, przywoływany w znaczeniu literalnym i wyznaczający ramę akceptowalnych asocjacji. Metafory tego typu odwołują się do powszechnej wiedzy o świecie, ujętej w poznawcze stereotypy, dlatego też interakcyjna teoria metafory zawsze odsyła do kulturowych aspektów języka. W jej świetle metafora przede wszystkim wydobywa nowe, dotychczas nieeksponowane znaczenie słowa, które choć rozumiane literalnie, nabiera innego nieznanego wcześniej wymiaru.

Według Blacka jednak metafora nie tylko wydobywa, ale w niektórych przypadkach wręcz stwarza nowe znaczenie. Dzieje się tak, gdy żaden z jej składników w złożonym procesie metaforyzacji nie oznacza już tego, co wypełnia jego wartość semantyczną poza daną metaforą, lecz każdy sygnalizuje zupełnie nowe treści. Rozwijając teorię metafory w kierunku jej twórczego aspektu Black wyodrębnił metaforę emfatyczną, czyli taką, której źródło ( tj. wyraz lub zwrot wprowadzony w dosłowne ramy w celu nadania mu sensu przenośnego) jest ze swej istoty niezastępowalne. Emfaza jest więc antonimem ekwiwalencji i wyklucza możliwość interpretacji metafory tego typu w ramach teorii substytucyjnej. Obok emfazy cechą twórczych metafor jest rezonans, który sprawia, że metafora nigdy nie wybrzmiewa do końca, nigdy też nie da się jej znaczeniowo domknąć. Między źródłem metafory a jej przedmiotem głównym (wyznaczającym ramę) nieustannie trwa oddziaływanie zachęcające do poszukiwania coraz to nowych znaczeń i sensów. Napięcie semantyczne, wynikające z projekcji źródła metafory na ramę, w której się ona dokonuje, zostało określone jako rezonans. Rezonans i emfaza mogą w różnym stopniu cechować wypowiedzi metaforyczne, pozostają jednak z sobą w pewnym związku. Zazwyczaj metafory o wysokim natężeniu emfazy są równocześnie silnie rezonujące. Ponadto cechujące się wspólistnieniem obu tych zjawisk wyrażenia metaforyczne mogą być mocne lub słabe. Za kryterium tego podziału Black uznał poziom ich nasycenia emfazą i rezonansem. Moc lub słabość metafory wiąże się więc bezpośrednio z ich wyrazistością emfatyczną i siłą rezonansu. Najwyższy poziom mocy okazują metafory poetyckie, które zbudowane na odległych, zaskakujących, lecz ciągle możliwych skojarzeniach, otwierają rozległą przestrzeń hermeneutyczną.

\section{Analiza materiału gwarowego}

Metafory proste

W pierwszej części proponuję poddać analizie wyrażenia metaforyczne o najprostszej konstrukcji rzeczownikowej, typu: snopek zycio, odziywacka nocy, wojki cetyny, kapeluse chałup, kozusek mrozu, zogłówek zorzy. We wszystkich zarówno źródła 
metafory, jak i jej ramy są wyrażone za pomocą pojedynczego słowa i odsyłają do codziennego doświadczenia życia. Źródła metafory: snopek, odziywacka, wojka, kapelus, kozusek, zogłówek w pełni należą do porządku gwary podhalańskiej. Jeśli zaś chodzi o ramę, w którą zostały wprawione, pojawiają się w jej roli wyrazy funkcjonujące zarówno w gwarze podhalańskiej (cetyna), jak i w innych (chałupa), a także w języku literackim (zorza, noc, życie, mróz). Zestawienie: gwarowe źródło, niegwarowa rama pozwala tym ostatnim nadać swojski wymiar i w ten sposób wprowadzić je do góralskiej mowy, wzbogacając jej zasoby leksykalne. Zakorzenienie zarówno przedmiotu metafory, jak i jej źródła w codziennym doświadczeniu sprawia, że przywołane zestawienia są odbierane jako naturalne, mimo że tworzące je przedmioty zwykle nie występują w takich konfiguracjach. Wszystkie przytoczone wyżej zestawienia są poetycką kreacją.

Przyjrzyjmy się bliżej wyrażeniu: odziywacka nocy. Aby pojąć jego metaforyczny sens, należy rozumieć znaczenie słowa odziywacka oraz znać wiążące się z nim potoczne skojarzenia. Ilustrowany leksykon gwary i kultury podhalańskiej (Kąś 2018, 261) podaje, iż odziywacka to 'gruba wełniana chusta $\mathrm{z}$ frędzlami, noszona głównie przez kobiety starsze, okrywająca głowę, ramiona i plecy'. Do lat 80 . XX w. była ona popularna wśród góralek, $\mathrm{z}$ czasem wyparta przez kurtki lub płaszcze, choć ciągle jeszcze spotykana na Podhalu. Mimo zmian odziywacka jest słowem powszechnie znanym i używanym. W zestawie banalnych skojarzeń związanych z tym przedmiotem pojawią się następujące asocjacje:

- duża chusta, zdolna okryć niemal całą postać;

- gruba tkanina;

- ochrona przed zimnem, deszczem, wiatrem;

- szczelne kobiece okrycie wierzchnie;

- raczej ciemny lub stonowany kolor (odziywacki, ponieważ były noszone głównie przez kobiety zamężne, przybierały zazwyczaj odcienie brązu, zieleni lub czerni, choć zdarzały się także i jaśniejsze barwy);

- wyznacznik zamożności (odziywacki świadczyły o bogactwie gaździny - im lepsza jakość materiału i oryginalniejszy wzór, tym większe bogactwo gospodyni).

Zestawienie odziywacki z noca uaktywnia najoczywistsze cechy wspólne np. ciemność, która jest wynikiem szczelnego przykrycia ziemi chustą z grubego materiału, ale też odkrywa inne, zaskakujące cechy nocy, które twórczo poszerzają jej znaczenie, przesuwając akcent z doświadczenia codziennego na poetyckie. Podkreśla m.in. przewagę nocy nad światem - jest od niego większa, może go spowić w całości. Niweluje jej grozę - noc otula ziemię szczelnie, aby ją chronić przed zimnem lub wiatrem, dzięki czemu mimo swej tajemniczości i ciemności jawi się ona jako coś swojskiego i bezpiecznego. Szlachetna uroda odziywacek zamożnych gospodyń potęguje odczucie piękna nocy i jej dostojności. W perspektywie powszechnej w folklorze skłonności do personifikacji zjawisk natury, wynikającej z bliskiej zażyłości człowieka z jej prawami, metafora odziywacka nocy przywołuje skojarzenia nocy z dojrzałą lub starszą kobietą, być może matką, która swoją odziywackom troskliwie okrywa świat. $\mathrm{Z}$ drugiej jednak strony można tę metaforę zinterpretować personifikując nie noc, lecz ziemię, która owija się szczelnie ciemną odziywackom. Niejednoznaczność tego 
wyrażenia sprawia, że jego ostateczne znaczenie pozostaje tajemnicą, skłaniającą do twórczej współpracy. Pośrednie nawiązanie do ludowego widzenia świata podwójnie służy gwarowej metaforze: pozwala osadzić ją w tradycji, a równocześnie podkreśla dystans, będący wynikiem indywidualnej, dalekiej od ludowej konwencji, artystycznej wizji świata. Analizowana metafora wykazuje wysoki poziom emfazy. Trudno znaleźć słowo, które mogłoby zastąpić odziywacke. Istnieje co prawda w gwarze wyraz chusta, lecz nie oznacza on części kobiecego stroju5. Metafora chusta nocy po pierwsze zupełnie inaczej modelowałaby znaczenie, w jakim noc została użyta $\mathrm{w}$ tym zestawieniu, a po drugie zatraciłaby już swoje góralskie brzmienie. Wysokiemu poziomowi emfazy odpowiada w metaforze odziywacka nocy także silny rezonans. Między polami semantycznymi źródła metafory i jej przedmiotu podstawowego można doszukiwać się coraz to innych interakcji, które wzbogacają treść całego wyrażenia i czynią je niezmiennie świeżym. Można więc uznać, że analizowana gwarowa metafora jest mocna i w pełni udana, ponieważ została oparta na góralskim doświadczeniu życia. Jeśli zaś chodzi o mechanizm jej powstania, w niczym nie różni się on od mechanizmów leżących u podstaw ogólnoliterackich metafor zbudowanych według podobnego modelu.

\section{Metafory złożone}

W tej części przed miotem analizy będą rozbudowane wyrażenia w znaczeniu przenośnym, których orzeczenie wprowadza zmetaforyzowany podmiot lub dopełnienie.

Oto pierwszy z przykładów, zaczerpnięty z wiersza Wandy Czubernatowej Paciorek do matcynyk ręcy.

Synkate stare babiny,

na wasyk ręcak cas pise

paciórki zylaste, siwe

zdrowaśki w węzły krzesane

Przytoczony fragment jest rodzajem lirycznej obserwacji, a nawet kontemplacji starości, prowadzonej na podstawie obserwacji rąk starych kobiet. Już pierwszy ogląd tego metaforycznego tekstu pozwala stwierdzić siłę jego emfazy. Emfaza ta ma zwielokrotniony wymiar. Pierwszy łączy się z gwarą jako językowym tworzywem wyrażenia metaforycznego. Przedmiotem metafory są przywołane w tytule ręce matek, źródłem zaś wyrażenia są pisane przez cas paciorki zylaste, siwe zdrowaśki krzesane $w$ węzły. Same matki także zostały w cytowanej strofie przywołane za pośrednictwem wyrażenia metaforycznego - synkate stare babiny. Dzięki gwarze czytelnik uświadamia sobie, że opis dotyczy góralskich matek. Nie chodzi o to, że gdzie indziej spracowane stare matki mają inne dłonie, ale właśnie o to, że wszystko, co jest powiedziane $\mathrm{w}$ tym tekście, odnosi się przede wszystkim do góralek, a $\mathrm{z}$ poszczególnych fraz

\footnotetext{
${ }^{5}$ Góralki ogólnopolskie chustki nazywają smatkami, grubsze i większe chusty to odziywacki, kaźmirkule, barankule, chusta zaś w podstawowym sensie oznacza płat lnianego płótna wykorzystywany do różnych celów, zwykle jednak niezwiązanych z ubiorem (Kąś 2015, 142-143).
} 
wyłania się ich konkretny obraz. Gwara jest tego wyraźnym i wystarczającym sygnałem. Sprawia też, że użyte przez poetkę wyrażenia metaforyczne są nie do zastąpienia ani przez paralelne wyrażenia literackie, ani też przez metafory zbudowane np. $z$ tworzywa gwar innych regionów. Gdyby je zastosować, powstałyby zapewne teksty o zupełnie innych kobietach. Gwarowy obraz góralskich matek (a w sugerowanym przez omawiany cytat węższym wymiarze - ich spracowanych rąk) jest mocno osadzony w kulturowym doświadczeniu regionu, do którego nawiązuje drugi wymiar emfazy wyrażeń metaforycznych użytych w tekście. Podkreśla to dobór źródeł poszczególnych metafor, odsyłających do sfery sacrum (paciórki, zdrowaśki). Ręce starych matek już nie pracują, lecz noszą na sobie znamiona pracowitego życia, które samo w sobie było formą modlitwy. Z drugiej strony pochłaniająca wiele czasu modlitwa jest wyznacznikiem i sygnałem starości. To właśnie stare, z punktu widzenia pragmatyki życia rodzinnego już nieużyteczne kobiety zapełniają kościelne ławki w czasie codziennych nabożeństw. Właśnie tam najłatwiej przyjrzeć się ich rękom, kiedy przesuwają paciorki różańca. Przytoczony cytat jest przykładem metafory wielopiętrowej. U jej podstaw leżą wyrażenia zylaste paciorki oraz siwe zdrowaśki w węzły krzesane. Metafora zylaste paciorki buduje obraz żył, którymi pokryte są ręce starych kobiet, a równocześnie przynosi ich sakralizację. Źródłem metafory są paciórki, zaś ramą - żyły (wyrażone za pomocą epitetu zylaste). Ewokowane przez każdy z tych składników metafory system skojarzeń jest wysoce nieoczywisty, a mimo to nietrudny do pojęcia. Oba te człony intensywnie rezonują, dzięki czemu pojawiają się coraz to nowe, inne, niebanalne skojarzenia, które pomagają raczej „odczuć” niż „zrozumieć” wyłaniający się z nich obraz. Bardziej rozbudowane wyrażenie siwe zdrowaśki $w$ węzły krzesane także odnosi się do żył widocznych na spracowanych dłoniach starych góralskich matek. Co prawda przedmiot metafory nie jest bezpośrednio przywołany, lecz zarówno rozbudowane źródło, jak również miejsce w porządku wiersza sprawiają, że w czytelny sposób jest on tożsamy z tym, do którego odnosiła się poprzednia. Żyły są więc siwymi (czyli niebieskimi) zdrowaśkami. Wyrażenie to jest trudne do eksplikacji za pośrednictwem systemu banalnych skojarzeń, ponieważ ich po prostu nie ma. Trzeba je sobie dopiero stworzyć pod wpływem tego zaskakującego zestawienia i na jego potrzeby. O żyłach dowiadujemy się także, że są $w$ węzly krzesane. Gwarowy czasownik krzesać znaczy 'obrabiać siekierą toporem boczne powierzchnie belek, słupów itp.; ciosać' (Kąś 2017: 190), krzesać w węzły może oznaczać tyle, co 'ociosywać nierówno'. Podobnie jak wcześniej, także i w tym wypadku trudno się odnieść do systemu skojarzeń tych czynności z żyłami na matczynych dłoniach. Emfazę tej metafory jesteśmy więc w stanie określić wyłącznie na podstawie mocy jej rezonansu. Siwe zdrowaśki w węzły krzesane w odniesieniu do żył mogą skutkować twórczymi próbami ustalenia ukrytych znaczeń, z których każde będzie o tyle właściwe, o ile pozwoli zrozumieć lub, co w tym wypadku wydaje się bardziej uzasadnione, odczuć w pełni bezmiar ciężkiego trudu, którego te ręce doświadczyły. Obie te metafory przywołują dosyć jednoznaczny obraz, który współgra z metaforycznym określeniem samych matek: sękate stare babiny. Określenie 'matka' jest przedmiotem wielu metafor zbudowanych przy użyciu różnorodnych źródeł, zależnych od intencji autora. Większość z tych, które są powszechnie znane, ewokuje pozytywne skojarzenia (por. Bartmiński 2008), tymczasem w omawianym przykładzie mamy do czynienia z metaforycznym określeniem sękata 
wzmacniającym i tak już negatywnie nacechowane wyrażenie staro babina. Podsumowując, wszystkie gwarowe źródła metaforycznego przedstawienia góralskich matek odsyłają odbiorcę do realiów twardego i niedocenionego życia, wypełnionego ciężką pracą, nieodwzajemnioną troską i niewysłuchaną modlitwą. Paradoksalnie jednak, dzięki tej surowej w doborze słów metaforyce, poetce udało się stworzyć jeden $\mathrm{z}$ najczulszych i najbardziej lirycznych obrazów góralskiej matki, jaki można znaleźć w gwarowej poezji Podhala.

Kolejny przykład rozbudowanej metafory został zaczerpnięty z pozbawionego tytułu wiersza Hanki Nowobielskiej, zaczynającego się od słów.

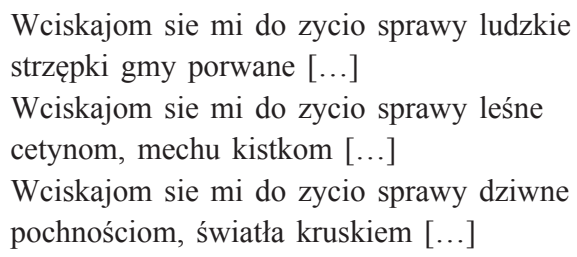

Trzykrotne powtórzenie zwrotu: wciskajom sie mi do zycio narzuca odbiorcy subiektywną i do pewnego stopnia wewnętrzną perspektywę oglądu prezentowanej w utworze rzeczywistości. Świat zewnętrzny pozostaje na dalszym planie. Czytelnik nie ma do niego bezpośredniego dostępu. Dane mu są natomiast tylko jego wybrane, przefiltrowane przez świadomość i emocje bohatera wiersza, dalekie echa. Umiejscowienie odbiorcy niejako we wnętrzu świadomości ja lirycznego stało się możliwe dzięki zastosowaniu szeregu metafor, z których każda jest wpisana kolejno w ramy: spraw ludzkich, spraw leśnych, spraw dziwnych.

Sprawy ludzkie są zestawione z metaforycznie użytymi porwanymi strzępkami gmy oraz śpiywonkami o jednyj nutce. Gma w gwarze podhalańskiej oznacza 'mgłę'. Mgła na Podhalu jest zjawiskiem częstym i spektakularnym. Czasami zalega tak nisko, że człowiek może na nią spojrzeć z góry, zwłaszcza kiedy, idąc ku szczytom, pozostawia ją za sobą. Bywa też jednak i tak, że mgła spowija cały świat, szczelnie go przesłaniając. Każdy góral wielokrotnie widział, jak gnane wiatrem niskie chmury przeciskają się między konarami drzew lub wydobywają zza ostrych grani, co sprawia wrażenie, jakby mgła była rozrywana na strzępy. Doświadczenie różnorodności tego zjawiska sprawia, że mgła budzi u górali nieco odmienne skojarzenia niż u mieszkańców innych regionów, co znajduje odzwierciedlenie w poetyckiej metaforyce (gma obłapi cie za nogi, gma wziena wieś pod swoje skrzydło, gme dre wiater na strzępki, gma stawio klostorny mur młodym jedlom itp.). Odmienność ta bierze się z kilku źródeł. Po pierwsze w górach mgła charakteryzuje się dużą dynamiką - przemieszcza się, wznosi i opada, napływa i odpływa, rozdziela się i łączy. Po drugie jest dosyć łagodnym zjawiskiem przyrody na tle innych, gwałtownych i destrukcyjnych, jak np.: wiatr halny, śnieżyce, mrozy, ulewne deszcze czy gwałtowne burze z piorunami. Trzecie skojarzenie z mgłą ma już charakter ogólny i dotyczy jej ulotności (mgła rzednie, rozprasza się, opada, ginie, rozpływa się). Także strzępki w gwarze podhalańskiej mają odmienne znaczenie. Słowem tym określa się rodzaj długich, zrobionych z cienkich nitek, delikatnych frędzli, którymi ozdabia się góralskie chustki (smatki). Jeśli więc sprawy 
ludzkie docierają do świadomości ja lirycznego porwanymi strzępami gmy, oznacza to, że są one nikłe, nieważne, nie zajmują zbyt wiele uwagi, nie jawią się jako całościowe problemy, które by mogły zdominować życie, niczemu też już się nie przysłużą. Dla pełnego odczytania omawianej metafory należy jeszcze dodać, że także przymiotnik ludzkie w gwarze podhalańskiej ma nieco inny wydźwięk niż w języku ogólnopolskim. Ilustrowany leksykon gwary i kultury podhalańskiej odnotowuje trzy znaczenia tego przymiotnika (Kąś 2017: 390); dwa pierwsze są tożsame z ogólnopolskimi (ludzki - 'właściwy człowiekowi', np. ludzkie zycie, lub w odniesieniu do człowieka - 'dobry, miły, rozumiejący innych', np. ludzki ctek), w trzecim natomiast określeniem tym oznacza się przedmioty 'należące do innych, cudze' (np. baca mo ludzkie owce - baca ma pod opieką owce innych gospodarzy). Poza tym słowo to w pewnych kontekstach służy także do określenia przedmiotów należących do ludzi ze wsi lub wspólnoty, z którą utożsamia się osoba mówiąca, w odróżnieniu od przedmiotów należących do obcych (np. ludzkie pola, czyli pola ludzi z naszej wsi [chłopskie], a nie np. pańskie czy żydowskie). Niejednoznaczność określenia sprawia, że użyte w tekście sprawy ludzkie budzą w rozumiejącym gwarę odbiorcy bogatsze asocjacje i zostawiają wiele niedopowiedzianych kwestii. Nawet jednak rozumiane dosłownie, czyli jako określenie wszystkiego, co dotyczy realnego świata, dzięki zestawieniu ich z porwanymi strzępkami gmy manifestują swoją znikomość. Sprawy ludzkie nie odgrywają więc większej roli w życiu lirycznej bohaterki wiersza; docierają do jej świadomości tylko częściowo i nigdy nie absorbują całej uwagi.

Rozpoczynające kolejne strofy wiersza sprawy leśne już same w sobie są metaforą, której znaczenia nie da się jednoznacznie wyeksplikować. W porządku wiersza ramą dla spraw leśnych są wcześniejsze sprawy ludzkie. Rama ta jednak zaledwie częściowo tłumaczy sens metafory, ponieważ sama w sobie, jak wykazano powyżej, nie jest wystarczająco jednoznaczna. Wyjaśnienia należy szukać w źródłach metafory, przypisanych temu wyrażeniu: sprawy leśne = cetyna, kistka mechu. Cetyna to nazwa gałęzi świerkowych lub jodłowych. W kulturze góralskiej oznacza ona z jednej strony rzecz bardzo przydatną w gospodarstwie (np. cetyną słano bydłu legowiska w oborze), ale też dekoracyjną (gałązki cetyny wkładano za ramy obrazów w dniu Wigilii, przystrajano nią domy, wito z niej wieńce). Każdy góral zna mocny, żywiczny zapach cetyny przyniesionej z lasu, którego stała się symbolem. Z kolei mech porastający pnie drzew i zacienione, wilgotne poszycia lasów także jest obecny w domowym gospodarstwie górali, ponieważ zwijany właśnie w kistki, czyli ciasne pukle, służył do zatykania szpar między płazami. Mech także przynoszono z lasu. Liryczny nastrój wiersza każe jednak zinterpretować tę metaforę w mniej pragmatycznym i dosłownym, a bardziej w poetyckim i symbolicznym kierunku. Cetyna i mech stają się „wysłannikami lasu”, przedstawicielami natury, która $\mathrm{w}$ ten sposób upomina się o należne sobie miejsce w życiu człowieka. Kwestie natury mają konkretniejszą reprezentację w świadomości bohaterki wiersza niż sprawy ludzkie, co oznacza, że przypisuje się im (sprawom leśnym) większe znaczenie i przyznaje ważniejsze miejsce.

Ostanie w cytowanym fragmencie sprawy dziwne są jeszcze bardziej niejasne. Dziwne mogą być zarówno sprawy ludzkie, jak i leśne, dlatego trudno znaleźć podstawę tak niespodziewanej dystynkcji. W wierszu sprawy dziwne manifestują się pochnościom i światta kruskiem. Wyrażenia te, będące źródłem metafory formującym 
znaczenie spraw dziwnych, odsyłają do niematerialnej sfery czystych doznań zmysłowych. Pochność w gwarze podhalańskiej znaczy 'miły zapach, przyjemna woń' i ma charakter poetyzmu. Częściej bowiem określenie to można spotkać w tekstach literackich niż w żywej gwarze, w której niewiele miejsca pozostawiano na werbalizowanie doznań o ulotnej i sensualnej naturze. Krusek natomiast jest wyrazem pochodzącym z potocznej mowy górali, oznacza 'okruch czegoś, fragment'. Mówi się więc o krusku soli lub wyngla. Krusek łączył się z rzeczownikami oznaczającymi przedmioty fizyczne, charakteryzujące się twardością materii. Aby odłupać krusek, trzeba było użyć siły oraz stosownego narzędzia. Tymczasem w wierszu Nowobielskiej pojawia się oksymoroniczny krusek światta, co nasuwa na myśl znaną powszechnie metaforę okruch światła. Gwarowy krusek budzi jednak nieco inne skojarzenia niż ogólnopolski okruch. Krusek jest miarą czegoś cennego, czego należy używać z umiarem, ze świadomością, że dane dobro jest limitowane. Zarówno pochność, jak i światta krusek pozwalają zinterpretować przedmiot metafory jako docierające przez zmysły oznaki bogactwa i piękna niematerialnego wymiaru świata.

Dzięki zastosowaniu przez Hankę Nowobielską trzech różnych źródeł metafory, ich sens stał się możliwy do odczytania, które jednak zawsze pozostanie niejednoznaczną interpretacją. Sprawy ludzkie oznaczają zatem prozę codziennych spraw i jako takie nie są zbyt absorbujące. Sprawy leśne odsyłają do świata natury, której człowiek jest częścią, dlatego też powinien jej poświęcać większą uwagę. Sprawy dziwne natomiast odnoszą się do sfery duchowej, która decyduje o tym, kim w rzeczywistości jesteśmy. Wszystkie zaś razem wyznaczają horyzont pełnej ludzkiej egzystencji. Metafory użyte przez Hankę Nowobielską pozostają jednak otwarte na alternatywne interpretacje i wciąż zachęcają do negocjowania nowych sensów.

Ostatnia metafora, charakteryzująca się najwyższym stopniem wewnętrznego złożenia, pochodzi z wiersza Józefa Pary-Hejki Pocytać wierśki. Aby lepiej zrozumieć jej wymowę, należy odczytać ją na tle przesłania całości tekstu. Wiersz powstał w latach 70. XX w., kiedy rodzima kultura na Podhalu przeżywała kryzys. Zmiany cywilizacyjne sprawiły, że górale coraz częściej porzucali dawne tradycje, których wówczas jeszcze nie umiano godzić z nowoczesnością. Zanikały stare obyczaje, a wraz z nimi gwara. W Tatrach zakazano wypasu owiec. Lansowany wówczas folkloryzm oddał osąd nad góralską kulturą w ręce ekspertów od ludowości, którzy zasiadali w gremiach oceniających występy uczestników różnorodnych konkursów, festiwali i przeglądów. Popularny wówczas serial o Janosiku budował fałszywy obraz górali, który mimo to utrwalił się w świadomości dużej części Polaków. Zjawiska te obudziły gwałtowny sprzeciw niektórych, bardziej świadomych wagi własnego dziedzictwa górali. Józef Para-Hejka należał do ich grona. Jako podhalański poeta z rozmysłem posługiwał się taką gwarą, która sprawiała trudność w odbiorze. Chciał w ten sposób wydzielić jakiś jej obszar, wolny od zewnętrznych ingerencji i wpływów, niedostępny dla obcych. Nie szczędził przy tym gorzkich słów ówczesnym animatorom życia kulturalnego na Podhalu. Z równą zajadłością krytykował także obojętną postawę samych górali. Nawoływał do podejmowania wysiłku i świadomej troski nie tylko o zachowanie rodzimej kultury, ale także o jej rozwój. W swoich działaniach był bezkompromisowy. Ostatecznie uznał przegraną, porzucił Podhale i zerwał z nim wszelkie kontakty. Wiersz Pocytać wierśki jest przykładem góralskiej poezji zaangażowanej w dzieło ratowania podhalańskiej 
odrębności kulturowej. W dużej części przynosi gwałtowną krytykę czasów i obyczajów, które nie tylko nie sprzyjały góralszczyźnie, ale wręcz jej zagrażały, także dlatego że sami górale zdradzili ją dla dularów.

Całość poeta zamyka następującym apelem:

Pocytać wierśki zwykem

zaklagać bocynkem

niedokońcony zomierędz w gródzy

wtej $[\ldots]$ parzenice ozkwitnom lelujnie

Hermetyczność tego tekstu bierze się przede wszystkim z przemieszania gwarowych archaizmów z neologizmami bądź z rzadko używanymi formami. Bocyć znaczy w gwarze 'pamiętać', ale bocynek nie należy już do powszechnego słownika. W Ilustrowanym leksykonie gwary $i$ kultury podhalańskiej został odnotowany bez kontekstu (Kąś 2015, 307), lecz z odsyłaczem do słownika Stanisława Hodorowicza, który włączył go do swojej kolekcji, także bezkontekstowo, tłumacząc jako 'pamięć, zapamiętanie' (Hodorowicz 2004, 8). Podobnie zomierędz, który jest odsłownym rzeczownikiem utworzonym od odnoszącego się do krów i owiec czasownika mieręzać, czyli 'przeżuwać'. Pochodzący od rzeczownika leluja przymiotnik lelujnie jest neologizmem autorstwa Pary-Hejki. Pozostałe słowa: zaklagać, pocytać, wierśki, zwyk, gródza, parzenica należą do tradycyjnego słownictwa gwarowego. W całym cytacie jedynie określenia niedokońcony i ozkwitnać nawiązują do polszczyzny ogólnej i są łatwo zrozumiałe (do powszechnie znanych wyrażeń można także zaliczyć parzenice). Pozostałe wymagają wiedzy wynikającej ze znajomości zarówno góralskiej codzienności, jak i tradycji. Mimo niejasności poszczególnych słów, stosunkowo łatwo odczytać z gramatycznej struktury tekstu, że pierwsze dwa zdania wskazują jakieś warunki, których spełnienie pozwoli urzeczywistnić obietnicę tkwiącą $\mathrm{w}$ ostatnim zdaniu, mówiącym o lelujnym ozkwicie parzenic.

Dla osiągnięcia artystycznego celu autor skonstruował wieloznaczną i skomplikowaną metaforę, nadając przenośny sens każdemu ze zdań. Pierwsze: pocytać wierśki zwykem zyskuje siłę wyrazu dzięki metaforycznemu użyciu słowa zwyk w kontekście cytania wierśków. Zwyk oznacza 'zwyczaj utrwalony tradycją'. Stare zwyki są traktowane jako matecznik góralszczyzny. Kto je kultywuje, ten pozostaje wierny ojcowskim nakazom. Zwyki trzeba znać, lecz nie da się ich wyuczyć z książek. Można je tylko przejąć od poprzedników i należy przekazać następcom. Cytać - oznacza 'liczyć' i ma głównie pasterskie konotacje. Wielokrotne cytanie owiec na hali należało do podstawowych obowiązków bacy, któremu gazdowie dali pod opiekę swoje owce. Z tego powodu w słowie cytać mieści się odcień odpowiedzialności za powierzone dobra (np. owce), z których trzeba będzie zdać sprawę właścicielom. Cytać w zestwieniu z wierśkami, czyli tatrzańskimi szczytami, oznacza więc - zorientować się w stanie góralskiego posiadania, ale także wziąć odpowiedzialność za to, co się posiada. Kiedy na tę treść nasunie się jeszcze pole tematyczne słowa zwyk, wyłoni się nakaz zachowania tradycyjnej góralskiej kultury i objęcia jej troską, jaką pasterz okazuje powierzonym sobie trzodom.

Drugi imperatyw każe: zaklagać bocynkem niedokońcony zomierędz w gródzy. To metaforyczne wyrażenie także odsyła do tradycji pasterskich. Klaganie mleka to jedna 
z podstawowych czynności przy wyrobie sera. Baca łączy podgrzane owcze mleko z podpuszczką ( $k l o g)$, a następnie specjalnym narzędziem rozbija powstającą masę serową, aby poddać ją dalszej obróbce. Klaganie jest czynnością, która zmienia mleko w ser, czyli ma moc sprawczą i twórczą. Z umiejętnie połączonych składników powstaje nowa jakość. Dla ratowania góralskiej kultury trzeba jednak zaklagać nie mleko, lecz niedokońcony zomierędz w gródzy. Gródza oznacza 'zagrodę', w której krowy lub owce odpoczywają po całodziennym wypasie i przeżuwają (mierędzom) spożyty pokarm. Aby całe pasterskie gospodarstwo działało sprawnie, trzeba, aby czynność ta dokonywała się w spokoju. Między ludźmi a powierzonymi im zwierzętami panowała równowaga. Każda ze stron otrzymywała swoją część, jeśli dotrzymała zobowiązań względem pozostałych. W podobny sposób działa tradycja. Opiera się na ciągłości i równowadze. Jeśli zostanie przerwana, cały skomplikowany układ zależności przestanie działać. A tak się właśnie stało. Coś przerwało spokojny zomierędz, czyli zaburzyło odwieczny proces. Należy więc naprawić tę sytuację. Należy postąpić jak mądry baca, który wie jak i kiedy zaklagać, aby powstał ser. Metaforycznym klagiem jest $z w y k$, czyli powrót do źródeł, do góralskich zwyczajów kultywowanych nie na scenie, ale w codziennym życiu. Spełnienie tych warunków sprawi, że parzenice ozkwitnom lelujnie, czyli na nowo odrodzi się góralska tradycja.

Gwarowa metaforyka Pary-Hejki mimo swego osadzenia w realiach góralskiego gospodarstwa i związanego z tym wysokiego poziomu emfazy, nie może uchodzić za wysoce rezonansową. Nagromadzenie trudnych do zrozumienia wyrazów komplikuje jej odbiór i ogranicza przestrzeń sensotwórczą, a ponadto zniechęca do wysiłku. Metafory Pary-Hejki są wysoce hermetyczne, przez co przekroczyły granicę, poza którą już nie ma pewności, czy użyte przenośnie słowa rzeczywiście kryją jakieś znaczenie, czy też może powstaje ono dopiero w mozolnym wysiłku prób ich właściwego odczytania, czyli de facto nadania im sensu. Jakkolwiek w całości odnoszą się one do pasterskiego doświadczenia życia i pracy, to jednak przed przeciętnym odbiorcą, nawet znającym gwarę i posługującym się nią na co dzień, stawiają zbyt wysoką barierę, przez co są odbierane jako dziwaczne i sztuczne. Trudno też jednoznacznie określić, czy kryje się za nimi typowo góralskie postrzeganie świata, w jakim zostały zakorzenione wcześniej omawiane metafory, np. Wandy Czubernatowej, czy też już do niego nie należą. W gwarowej poezji Podhala jednak tego typu złożone przenośnie są rzadko spotykane, co zapewne należy tłumaczyć zasadą ekonomiki wysiłku zarówno tworzenia, jak i odbioru poezji.

\section{Podsumowanie}

We współczesnej gwarowej poezji Podhala istotną rolę odgrywają oryginalne metafory artystyczne, które bądź twórczo przekształcają ludowe konwencje, bądź też kreują indywidualny świat lirycznej wypowiedzi. W obu przypadkach cechuje je niekonwencjonalne podejście do gwary. Poeta świadomie poddaje ją swoistym przekształceniom semantycznym, poszerzającym pole znaczeniowe użytych słów lub też tworzącym nowe sensy. Metafora gwarowa co do istoty w zasadzie niczym nie różni się od metafory stosowanej $\mathrm{w}$ polskiej poezji współczesnej. Obie są budowane na podobnych 
mechanizmach, które dają się opisać za pomocą interakcyjnej teorii Blacka. Gwarowa metafora jednak jest w odbiorze trudniejsza od swej ogólnopolskiej odpowiedniczki. Dostęp do pełni ewokowanych przez nią sensów wymaga dobrej znajomości gwary, jej wieloznaczności, a także potencjału sensotwórczego. Zarówno tworzenie, jak i odczytywanie gwarowych przenośni nie może się także obyć bez ugruntowanej wiedzy na temat kultury Podhala w jej wielorakich aspektach.

Mimo tych trudności metafora jest jednym z podstawowych i najskuteczniejszych sposobów wyrażania treści abstrakcyjnych za pomocą języka gwarowego. Dzięki niej gwarowa liryka jest w ogóle możliwa. Góralski poeta zestawiając w niebanalnych połączeniach potoczne, gwarowe słowa lub łącząc je z odpowiednio dobranymi poetyzmami pochodzącymi z polszczyzny literackiej, usprawnia gwarę, poszerza jej możliwości, przyczynia się do jej rozwoju, tworzy jej artystyczną odmianę. Gwara zyskuje przy tym funkcję poetycką, czyli staje się celem sama w sobie.

Trud gwarowej metafory odczuwa nie tylko jej odbiorca, ale także i twórca. Wychodząc poza konwencje folkloru, staje na niepewnym gruncie. Nie każdą metaforę można uznać za fortunną. Problem, z którym musi się zmierzyć góralski poeta, polega na tym, aby wydobywane $\mathrm{z}$ gwarowych słów przenośne sensy nie stały w sprzeczności z samą gwarą, aby otwierając nowe perspektywy poznawcze, nadal pozostawały zakorzenione $\mathrm{w}$ gwarowym systemie językowym, aby wreszcie nie stały w sprzeczności z góralskim sposobem myślenia i odczuwania świata. Pogłębiona eksploatacja słowa ujętego metaforycznie, o ile jest fortunna i przynosi zamierzony efekt, służy gwarze jeszcze na jeden sposób. Sprawia, że wyrazy, które już nie mają racji bytu we współczesnym świecie, pojawiają się w tekstach literackich i w nich znajdują drugie życie (np. odziywacka). Ocalone od zapomnienia w swoim podstawowym znaczeniu, zyskują nowe, metaforyczne. Dzięki temu nadal są potrzebne i ciągle się ich używa.

Gwarowa liryka podhalańska, mimo że zawsze była zjawiskiem marginalnym i dosyć trudnym w odbiorze (także dla samych górali), odegrała i wciąż odgrywa znaczącą rolę nie tylko w zachowaniu gwary, ale także w jej nieustannej kultywacji. Zindywidualizowana, pogłębiona wrażliwość liryczna nie tylko nie stała się dla współczesnych poetów podhalańskich powodem do porzucenia gwary, lecz wręcz przeciwnie - udoskonaliła ją i uczyniła wrażliwszą, przy równoczesnym zachowaniu jej autentyzmu i nieprzekraczaniu granic wiarygodności.

\section{Literatura}

Bartmiński J., (1990), Folklor - język - poetyka, Wrocław-Warszawa-Kraków-Gdańsk-Łódź.

Bartmiński J., (2001), Ludowy styl artystyczny, [w:] Wspótczesny język polski, red. J. Bartmiński, Lublin, s. 223-234.

Bartmiński J., (2008), Polski stereotyp matki, „Postscriptum Polonistyczne”, z. 1 (1), s. 33-53.

Black M., (1971), Metafora, przeł. J. Japola, „Pamiętnik Literacki”, z. 3 (62), s. 217-234.

Black M., (1983), Jeszcze o metaforze, „Pamiętnik Literacki”, z. 2 (74), s. 255-281.

Głowiński M., (1988), Kultura literacka, [w:] M. Głowiński, T. Kostkiewiczowa i in., Stownik terminów literackich, Wrocław-Warszawa-Kraków-Gdańsk-Łódź, s. 245. 
Hodorowicz S., (2004), Stownik gwary górali Skalnego Podhala, Nowy Targ.

Kąś J., (2015), Ilustrowany leksykon gwary i kultury podhalańskiej, t. I, Bukowina TatrzańskaNowy Sącz.

Kąś J., (2017), Ilustrowany leksykon gwary i kultury podhalańskiej, t. V, Nowy Sącz.

Lakoff G., Johnson M., (1988), Metafory w naszym życiu, przeł. T.P. Krzeszowski, Warszawa.

Mlekodaj A., (2015), Kwietno pani. O gwarowej poezji Podhala w ujęciu kulturowym, RabkaZdrój.

Sławiński J., (1998), Socjologia literatury i poetyka historyczna, [w:] J. Sławiński, Prace wybrane, t. 2. Dzieło - język - tradycja, red. W. Bolecki, Kraków, s. 33-63. 